Emir. J. Food Agric. 2008. 20 (2): 01-09

http://www.cfa.uaeu.ac.ae/research/ejfa.htm

\title{
Comparative evaluation of different organic fertilizers on the soil fertility, leaf minerals composition and growth performance of dikanut seedlings (Irvingia gabonnesis L.)
}

\section{E. I. Moyin-Jesu}

\section{Agronomy Department, Federal College of Agriculture, Akure, Ondo State, Nigeria}

\begin{abstract}
An experiment was carried out at Akure in the rainforest zone of Nigeria to determine the effectiveness, of ten organic fertilizers on plant growth, soil fertility, and leaf nutrients composition of dikanut seedlings in the nursery. The organic fertilizer treatments were applied at $8 \mathrm{t} / \mathrm{ha}(40 \mathrm{~g} / 10 \mathrm{~kg}$ soil) to each polybag, a reference treatment NPK 15-15-15 compound fertilizer applied at $2 \mathrm{~g} \mathrm{NPK} / 10 \mathrm{~kg}$ soil $(400 \mathrm{~kg} / \mathrm{ha}$ ) and a control treatment (no chemical fertilizer nor manure), arranged in a completely randomized design (CRD) and replicated four times. The results showed that the organic fertilizers increased the seedlings' growth significantly $(\mathrm{P}<0.05)$, leaf and soil $\mathrm{N}, \mathrm{P}, \mathrm{K}, \mathrm{Ca}, \mathrm{Mg}$, soil $\mathrm{pH}$ and O.M of dikanut compared to the control treatment. The oil palm bunch ash + poultry manure increased the plant height, leaf area, stem girth, leaf numbers and root length of dikanut seedlings by $22 \%, 50 \%, 33 \%, 21 \%$ and $49 \%$ respectively, when compared to the NPK chemical fertilizer treatment. It also increased the leaf $\mathrm{N}, \mathrm{P}, \mathrm{K}, \mathrm{Ca}$ and $\mathrm{Mg}$ of dikanut seedlings by $35 \%, 37 \%, 39 \%, 36 \%$ and $65.3 \%$ respectively compared to the sole application of poultry manure. Oil palm bunch ash + poultry manure treatment increased the soil $\mathrm{pH}, \mathrm{O} . \mathrm{M}, \mathrm{N}$. P, $\mathrm{K}, \mathrm{Ca}, \mathrm{Mg}$ by $6 \%, 13 \%, 19 \%, 28 \%, 32 \%, 33 \%$ and $21 \%$ respectively compared to the cocoa husk + spent grain treatment. Therefore the, oil palm bunch ash + poultry manure applied at $8 \mathrm{t} /$ ha was the most effective treatment in increasing growth, soil and leaf parameters of dikanut seedlings.
\end{abstract}

Key words: Organic fertilizers, soil fertility, leaf mineral composition, growth performance and dikanut seedlings. 


\section{Introduction}

Dikanut (Irvingia gabonnesis) or wild bush mango is a tree occurring in wet forests of the tropics. It is about 20 metres or more in height and belongs to the family Irvingeaceae. The fruit pulp is eaten like that of mango, and the kernels are ground to make a thick paste used to fortify stews with a characteristic aroma.

Despite the usefulness of the crop, the major production problems facing its commercial production are that, the crop is going fast into extinction because of the difficulty in raising it from seeds in the nursery and a continued decline in soil fertility. Attempts to augment the soil nutrient status with inorganic fertilizers to enhance the germination and growth of dikanut are limited by the high cost of purchase, acute scarcity and degradation of soil properties on continuous use (MoyinJesu, 2004).

Therefore, it is necessary to look for alternative, locally sourced organic materials that are inexpensive, sustainable and environmentally compatible to raise dikanut seedlings in the nursery, as well as the field for large scale plantations; so that the cost of production will be low and within the financial solvency of the resource farmers.

Except the research works of Obatolu (1995), Moyin-Jesu and Atoyosoye (2002), Moyin-Jesu (2003), Moyin-Jesu and Ojeniyi (2006) and Odedina et al. (2007); there is paucity of research information on the use of oil palm bunch ash, cocoa pod husk, turkey and poultry manures and spent grain to raise dikanut both at the seedling stage and field conditions. Therefore, the objectives of the research are to determine the effect of different organic fertilizers on the growth performance of dikanut seedlings in the nursery; and the effect of these organic fertilizers on the soil and leaf chemical composition of dikanut.

\section{Materials and Methods}

The experiments were carried out in Akure $\left(7^{\circ} \mathrm{N}\right.$ ', $\left.5^{\circ} 10^{\prime} \mathrm{E}\right)$ in the rainforest zone of Nigeria in 2000 and was repeated in 2001 in order to validate the results. The type of soil is sandy loam, skeletal, kaolinitic, isohyperthermic oxic paleustalf (Alfisol) or Ferric Luvisol (FAO); while the annual rainfall is $1300 \mathrm{~mm}$ and the average temperature is $70^{\circ} \mathrm{F}$.

\section{Soil analysis before planting}

Samples of the soils used for the raising of dikanut seedlings were taken from the surface $(0-15 \mathrm{~cm})$, air-dried and sieved for routine soil analysis. The particle size analysis was done using the hydrometer method (Gee and Bauder, 1986). The soil $\mathrm{pH}(1: 1$ soil/water and $1: 2$ soil/0/01M $\mathrm{CaCl}_{2}$ solutions) was determined using a glass/calomel electrode system (Ogunwale and Udo, 1998). The organic matter was determined by the (AOAC, 1990).

The soil $\mathrm{K}, \mathrm{Ca}$ and $\mathrm{Mg}$ were extracted with $\mathrm{IM} \mathrm{NH}_{4} \mathrm{OAC}$, pH 7 and their amounts determined on the flame photometer using appropriate element filters. The $\mathrm{Mg}$ content was read on an atomic absorption spectrophotometer (Igwe et al., 2005). The exchangeable acidity $\left(\mathrm{H}^{+}\right.$and $\left.\mathrm{Al}^{3+}\right)$ was measured from $0.01 \mathrm{M} \mathrm{KCl}$ extracts by titrating with $0.1 \mathrm{M} \mathrm{HCl}$ (Blakes and Hartge, 1986).

Percent $\mathrm{N}$ was determined using the microkjedahl method (Ogunwale and Udo, 1998). Available $P$ was extracted using Bray P1 extractant and the extract was measured with the Murphy-Riley blue method (AOAC, 1990) on a spectronic 20 instrument at $882 \mathrm{~mm}$.

\section{Collection of organic materials and processing}

The poultry, turkey manures, oil palm bunch ash and cocoa husk were obtained from the livestock unit, oil palm and cocoa plantations at the Federal College of Agriculture, Akure; while the spent grain 
was collected from the International Breweries Limited, Ilesa, Osun State.

The organic materials were processed to allow decomposition. The dried cocoa pod husk was ground using a hammer mill. The oil palm bunch wastes were burnt into ash and spent grain was partially composted. The poultry and turkey manures were stacked to allow quick mineralization processes.

\section{Chemical analysis of the organic materials}

The powdered forms of the organic materials were analysed for the determination of the percentage of $\mathrm{P}, \mathrm{K}$, $\mathrm{Ca}, \mathrm{Mg}$ and $\mathrm{Na}$ using the wet digestion method based on 25-5-5 ml $\mathrm{HNO}_{3}-$ $\mathrm{H}_{2} \mathrm{SO}_{4}-\mathrm{HClO}_{4}$ acids (AOAC, 1990) while the percentage of $\mathrm{N}$ was determined by the microkjedahl method (Ogunwale and Udo, 1998).

\section{Pre-nursery establishment of dikanut seedlings}

A shed was erected to protect the germinating seed from excessive evaporation. Viable dikanut seeds were collected, processed, and sown into a seedbox of $1 \mathrm{~m} \times 60 \mathrm{~cm} \times 35 \mathrm{~cm}$ filled with top soil, mulched and watered regularly. The planted seeds germinated 35 days after planting.

\section{Nursery experiment}

$10 \mathrm{~kg}$ of surface soil $(0.15 \mathrm{~cm})$ taken from the experiment site was weighed into each of black polythene bag $\left(1400 \mathrm{~cm}^{3}\right)$ and arranged on the flat ground. The set-up was watered and allowed to equilibrate at field capacity for 48 hours.

There were ten organic fertilizer treatments, namely poultry manure, turkey manure, oil palm bunch ash, spent grain, oil palm bunch ash + spent grain, cocoa husk + turkey manure, spent grain + poultry manure, oil palm bunch ash + poultry manure, cocoa husk + spent grain, spent gain + turkey manure applied at $40 \mathrm{~g} / 10 \mathrm{~kg}$ soil (8t/ha); while NPK 15-15-15 was applied at $2 \mathrm{~g} / 10 \mathrm{~kg}$ soil sieved as reference treatment, and the control treatment did not receive neither manure nor fertilizer. The amendment of the plant residues with manures were done at a ratio of 50:50 by weight ( $20 \mathrm{~g}$ each).

The treatments were replicated four times and arranged in a completely randomized design (CRD). They were thoroughly mixed with the soils in polybags using a hand fork ten days before planting germinated dikanut seeds.

One germinated dikanut seed was planted per bag and a shade was built to prevent the seedlings from being scorched by the sun and watered daily. Weeding was carried out 2, 4, 6 and 10 weeks after transplanting. $4 \mathrm{ml}$ a.i. of karate in $12 \mathrm{~L}$ of water was also sprayed on the site every 3 weeks to control termite attack and pest infestation.

Measurements of the plant height, leaf population, leaf area and stem girth were taken starting two weeks post-transplantion continued every week until 15 weeks after transplanting (WAT) while the root length was determined at the time of the final transplantation to the field at 22 weeks after transplanting (WAT).

\section{Leaf analysis of dikanut seedlings}

Fresh leaf samples were taken 18 weeks after transplanting the dikanut seedlings and put into labeled envelopes, oven-dried for 2 days at $70^{\circ} \mathrm{C}$ to obtain oven-dry leaf samples, milled into powdered forms. $2 \mathrm{~g}$ of the samples were weighed for dry ashing in a muffle furnace at $500^{\circ} \mathrm{C}$ for 6 hours.

The extracts collected were analysed for percentage of $\mathrm{N}, \mathrm{P}, \mathrm{K}, \mathrm{Ca}$ and $\mathrm{Mg}$ as described earlier (AOAC, 1990).

\section{Soil analysis after the experiment}

At 24 weeks after transplanting, soil samples were taken from each polybag, air-dried, sieved and analysed for nutrient contents as described earlier.

\section{Statistical analysis}

The average data obtained for plant height, leaf area, stem girth, leaf 
population, root length, leaf and percentage of soil $\mathrm{N}, \mathrm{P}, \mathrm{K}, \mathrm{Ca}, \mathrm{Mg}$, soil $\mathrm{pH}$ and O.M. of dikanut seedlings were analysed using an ANOVA F-test. The treatments' means were compared using Duncan Multiple Range Test (DMRT) at a 5\% level (Steel et al., 1997).

\section{Results}

\section{Soil fertility evaluation before planting} The soil fertility status before planting dikanut seedlings is presented in Table 1.
The soil is slightly acidic with $\mathrm{pH}\left(\mathrm{H}_{2} \mathrm{O}\right)$ 6.3 and has very low organic matter $(0.26 \%)$. The percent of $\mathrm{N}$ is less than $0.15 \%$ and considered optimum for oil palm, kolanut and coconut tree (MoyinJesu, 2004).

The soil $\mathrm{P}$ is less than $10 \mathrm{mg} / \mathrm{kg} \mathrm{P}$ considered optimum for crops (Odedina et al., 2007) while $\mathrm{K}, \mathrm{Ca}, \mathrm{Mg}$ and $\mathrm{Na}$ values were lower than $0.2 \mathrm{mmol} / \mathrm{kg}$ critical levels considered adequate for kolanut and coconut.

Table 1. Soil chemical composition before planting dikanut seedlings.

\begin{tabular}{|c|c|c|c|c|c|c|c|c|c|}
\hline \multirow{2}{*}{\multicolumn{2}{|c|}{ pH }} & \multirow{3}{*}{$\begin{array}{c}\begin{array}{c}\text { Organic } \\
\text { matter }\end{array} \\
\%\end{array}$} & \multirow{3}{*}{$\mathbf{N}$} & \multirow{3}{*}{$\begin{array}{c}\mathbf{P} \\
\mathrm{mg} / \mathrm{kg} \\
\text { soil }\end{array}$} & \multicolumn{4}{|c|}{ Exchangeable cations } & \multirow{3}{*}{$\begin{array}{r}\begin{array}{r}\text { Bulk } \\
\text { density }\end{array} \\
\mathrm{mgm}^{-3}\end{array}$} \\
\hline & & & & & $\mathbf{K}$ & $\mathbf{C a}$ & Mg & $\mathbf{N a}$ & \\
\hline $\mathrm{H}_{2} \mathrm{O}$ & $\mathrm{CaCl}_{2}$ & & & & \multicolumn{4}{|c|}{$\mathrm{mmol} / \mathrm{kg}$} & \\
\hline 6.30 & 5.80 & 0.26 & 0.10 & 8.64 & 0.10 & 0.08 & 0.15 & 0.06 & 1.60 \\
\hline
\end{tabular}

\section{Chemical analysis of the organic fertilizers}

The chemical analysis of the organic fertilizers used for raising dikanut seedlings is shown in Table 2. Oil palm bunch ash and cocoa husk had the highest values of $\mathrm{P}, \mathrm{K}$ and $\mathrm{Mg}$ compared to the spent grain.

The turkey manure had higher values of $\mathrm{P}, \mathrm{K}$ and $\mathrm{Mg}$ than the poultry manure while poultry manure, contained higher $\%$ $\mathrm{N}, \mathrm{Ca}$ and Na than turkey manure.

\section{Leaf nutrients composition of dikanut under different organic fertilizers}

There were significant increases $(\mathrm{P}<0.05)$ in the leaf $\mathrm{N}, \mathrm{P}, \mathrm{K}, \mathrm{Ca}$ and $\mathrm{Mg}$ of dikanut seedlings at 18 weeks after transplanting under different organic fertilizers compared to the control treatment (Table 3).

When compared to the sole application of poultry manure, oil palm bunch ash + poultry manure treatment increased the leaf $\mathrm{N}, \mathrm{P}, \mathrm{K}, \mathrm{Ca}$ and $\mathrm{Mg}$ of the dikanut seedlings by $35 \%, 37 \%, 39 \%, 36 \%$ and $65.3 \%$ respectively.

Among the amended organic fertilizers applied, oil palm bunch ash + poultry manure treatment had the highest values of leaf nutrients $\mathrm{N}, \mathrm{P}, \mathrm{K}$ and $\mathrm{Ca}$; while spent grain + poultry manure had the highest $\mathrm{Mg}$ values.

For the sole forms of the organic fertilizers, poultry manure had the highest values of leaf $\mathrm{N}, \mathrm{P}, \mathrm{K}, \mathrm{Ca}$ and $\mathrm{Mg}$ followed by turkey manure and spent grain respectively.

The oil palm bunch ash + poultry manure treatment increased values of $\% \mathrm{~N}$, $\mathrm{Ca}$ and $\mathrm{Mg}$ in the leaf, compared to the NPK fertilizer by $1 \%, 95 \%$ and $98 \%$. However, NPK 15-15-15 increased the leaf $\mathrm{K}$ by $18 \%$ compared to the former treatment.

For the sole forms of the organic residues, the poultry manure treatment had the best leaf $\mathrm{N}, \mathrm{P}, \mathrm{K}, \mathrm{Ca}$ and $\mathrm{Mg}$ values followed by turkey manure and spent grain respectively. 
Emir. J. Food Agric. 2008. 20 (2): 01-09

http://www.cfa.uaeu.ac.ae/research/ejfa.htm

Table 2. Chemical analysis of the organic fertilizers used for raising dikanut seedlings.

\begin{tabular}{|c|c|c|c|c|c|c|}
\hline Organic fertilizers & $\mathbf{N}$ & $\mathbf{P}$ & $\mathbf{K}$ & $\mathbf{C a}$ & Mg & $\mathbf{N a}$ \\
\hline & $\%$ & \multicolumn{5}{|c|}{$\mathrm{mg} / \mathrm{kg}$} \\
\hline Spent grain & 0.78 & 76.00 & 7.86 & 0.13 & 3.10 & 4.57 \\
\hline Turkey manure & 2.59 & 380.20 & 12.26 & 2.80 & 4.40 & 5.80 \\
\hline Poultry manure & 4.53 & 376.10 & 10.62 & 2.90 & 2.90 & 6.10 \\
\hline Oil palm bunch ash & 1.76 & 110.20 & 15.34 & 24.10 & 9.10 & 4.82 \\
\hline Cocoa pod husk & 0.78 & 95.10 & 11.14 & 21.72 & 8.41 & 5.42 \\
\hline
\end{tabular}

Table 3. The leaf chemical of dikanaut seedlings under different organic residues.

\begin{tabular}{lccccc}
\hline 「reatments & $\mathbf{N}$ & $\mathbf{P}$ & $\mathbf{K}$ & $\mathbf{C a}$ & $\mathbf{M g}$ \\
\cline { 2 - 6 } & & & $\mathbf{\%}$ & & \\
\hline Control (no fertilizer) & $0.03 \mathrm{a}$ & $0.016 \mathrm{a}$ & $0.03 \mathrm{a}$ & $0.04 \mathrm{a}$ & $0.05 \mathrm{ab}$ \\
NPK 15-15-15 & $2.80 \mathrm{~h}$ & $0.5 \mathrm{i}$ & $0.60 \mathrm{i}$ & $0.03 \mathrm{a}$ & $0.01 \mathrm{a}$ \\
Spent grain & $0.46 \mathrm{~b}$ & $0.19 \mathrm{~b}$ & $0.22 \mathrm{~b}$ & $0.32 \mathrm{c}$ & $0.14 \mathrm{c}$ \\
Turkey manure & $1.52 \mathrm{~d}$ & $0.24 \mathrm{c}$ & $0.20 \mathrm{~b}$ & $0.25 \mathrm{~b}$ & $0.30 \mathrm{e}$ \\
$\begin{array}{l}\text { Poultry manure } \\
\text { Oil palm bunch ash }\end{array}$ & $1.83 \mathrm{e}$ & $0.32 \mathrm{e}$ & $0.30 \mathrm{~d}$ & $0.36 \mathrm{~cd}$ & $0.18 \mathrm{~cd}$ \\
$\begin{array}{l}\text { Spent grain + turkey } \\
\text { manure }\end{array}$ & $0.62 \mathrm{c}$ & $0.27 \mathrm{~cd}$ & $0.25 \mathrm{bc}$ & $0.30 \mathrm{c}$ & $0.36 \mathrm{f}$ \\
$\begin{array}{l}\text { Cocoa pod husk }+ \\
\text { spent grain }\end{array}$ & $2.58 \mathrm{~g}$ & $0.41 \mathrm{~g}$ & $0.38 \mathrm{ef}$ & $0.46 \mathrm{e}$ & $0.38 \mathrm{f}$ \\
$\begin{array}{l}\text { Oil palm bunch ash }+ \\
\text { spent grain }\end{array}$ & $2.35 \mathrm{f}$ & $0.39 \mathrm{fg}$ & $0.42 \mathrm{fg}$ & $0.38 \mathrm{~d}$ & $0.31 \mathrm{e}$ \\
$\begin{array}{l}\text { Spent grain }+ \text { poultry } \\
\text { manure }\end{array}$ & $2.44 \mathrm{f}$ & $0.42 \mathrm{gh}$ & $0.44 \mathrm{~g}$ & $0.52 \mathrm{f}$ & $0.46 \mathrm{~g}$ \\
$\begin{array}{l}\text { Cocoa husk + turkey } \\
\text { manure }\end{array}$ & $2.66 \mathrm{~g}$ & $0.43 \mathrm{~h}$ & $0.42 \mathrm{fg}$ & $0.48 \mathrm{e}$ & $0.62 \mathrm{i}$ \\
$\begin{array}{l}\text { Oil palm bunch ash }+ \text { poultry } \\
\text { manure }\end{array}$ & $2.39 \mathrm{f}$ & $0.36 \mathrm{ef}$ & $0.34 \mathrm{de}$ & $0.31 \mathrm{c}$ & $0.35 \mathrm{ef}$ \\
\hline
\end{tabular}

Treatment means followed by the same letters are not significantly different from each other using Duncan Multiple Range Test (DMRT) at 5\% level.

\section{Growth parameters of the dikanut seedlings}

There were significant increases $(\mathrm{P}<0.05)$ in plant height, leaf area, stem girth, leaf numbers and root length of dikanut seedlings between 2-15 weeks after transplanting (WAT) under different organic fertilizer treatments compared to the control treatment (Table 4).
Oil palm bunch ash + poultry manure treatment had the highest values of growth parameters in dikanut seedlings followed by spent grain + poultry manure and cocoa husk + turkey manure treatments respectively. Generally, all the amended treatments increased the growth parameters more than their sole forms.

When compared to NPK 15-15-15 fertilizer, oil palm bunch ash + poultry 
manure increased the plant height, leaf area, stem girth, leaf numbers and root length of dikanut seedlings by $22 \%, 50 \%$, $33 \%, 21 \%$ and $49 \%$ respectively.

Among the sole residues applied, poultry manure increased the growth parameters of dikanut seedlings the most, followed by turkey manure, oil palm bunch ash and spent grain treatments respectively.

Table 4. The mean values of growth parameters of dikanut seedlings under different plant residues.

\begin{tabular}{|c|c|c|c|c|c|}
\hline Treatments & $\begin{array}{c}\text { Plant } \\
\text { height }(\mathrm{cm})\end{array}$ & $\begin{array}{l}\text { Leaf area } \\
\quad\left(\mathrm{cm}^{2}\right)\end{array}$ & $\begin{array}{c}\text { Stem } \\
\operatorname{girth}(\mathrm{cm})\end{array}$ & $\begin{array}{c}\text { Leaf } \\
\text { numbers }\end{array}$ & $\begin{array}{c}\text { Root } \\
\text { length }(\mathrm{cm})\end{array}$ \\
\hline Control (no fertilizer) & $8.83 a$ & $20.72 a$ & $0.40 \mathrm{a}$ & $2.57 \mathrm{a}$ & $8.00 \mathrm{a}$ \\
\hline NPK 15-15-15 & 30.06de & $43.66 \mathrm{~b}$ & $0.91 b$ & $4.13 b$ & $13.00 \mathrm{~b}$ \\
\hline Spent grain & $20.30 \mathrm{~b}$ & $47.76 \mathrm{bc}$ & $0.95 b$ & $4.38 \mathrm{bc}$ & $18.00 \mathrm{c}$ \\
\hline Turkey manure & $27.81 \mathrm{c}$ & $59.38 \mathrm{~d}$ & $1.00 \mathrm{bc}$ & $4.32 \mathrm{~b}$ & $17.60 \mathrm{c}$ \\
\hline Poultry manure & $27.87 \mathrm{~cd}$ & $59.88 \mathrm{~d}$ & $1.05 \mathrm{c}$ & $4.40 \mathrm{bc}$ & $18.00 \mathrm{c}$ \\
\hline Oil palm bunch ash & $21.15 \mathrm{c}$ & $52.25 \mathrm{c}$ & $0.98 \mathrm{bc}$ & $4.22 b$ & $18.00 \mathrm{c}$ \\
\hline $\begin{array}{l}\text { Spent grain + turkey } \\
\text { manure }\end{array}$ & 29.76de & $66.50 \mathrm{e}$ & $1.12 \mathrm{~d}$ & $4.92 d$ & $20.00 \mathrm{~d}$ \\
\hline $\begin{array}{l}\text { Cocoa pod husk + } \\
\text { spent grain }\end{array}$ & $28.65 d$ & $61.21 \mathrm{~d}$ & $1.04 \mathrm{c}$ & $4.92 d$ & $21.30 \mathrm{de}$ \\
\hline $\begin{array}{l}\text { Oil palm bunch ash }+ \\
\text { Spent grain }\end{array}$ & $31.10 \mathrm{e}$ & $60.20 \mathrm{~d}$ & $1.08 \mathrm{~cd}$ & $4.96 \mathrm{~d}$ & $22.00 \mathrm{e}$ \\
\hline $\begin{array}{l}\text { Spent grain }+ \text { poultry } \\
\text { manure }\end{array}$ & $35.20 \mathrm{~g}$ & $62.92 d$ & $1.19 \mathrm{e}$ & $5.08 \mathrm{de}$ & $23.00 \mathrm{ef}$ \\
\hline $\begin{array}{l}\text { Cocoa husk + turkey } \\
\text { manure }\end{array}$ & $32.10 \mathrm{ef}$ & $67.98 \mathrm{ef}$ & $1.09 \mathrm{e}$ & $4.92 d$ & $24.80 \mathrm{~g}$ \\
\hline $\begin{array}{l}\text { Oil palm bunch ash }+ \\
\text { poultry manure }\end{array}$ & $38.30 \mathrm{~h}$ & $86.62 f$ & $1.36 \mathrm{f}$ & $5.25 \mathrm{ef}$ & $35.00 \mathrm{~h}$ \\
\hline
\end{tabular}

Treatment means followed by the same letters are not significantly different from each other using Duncan Multiple Range Test (DMRT) at 5\% level.

\section{Soil chemical composition after the experiment}

There were significant increases $(\mathrm{P}<0.05)$ in the soil $\mathrm{N}, \mathrm{P}, \mathrm{K}, \mathrm{Ca}, \mathrm{Mg}, \mathrm{pH}$ and O.M after having used the organic materials as compared to the control treatment (Table 5).

Among the amended treatments, the oil palm bunch ash + poultry manure had the best values of soil $\mathrm{N}, \mathrm{P}, \mathrm{K}, \mathrm{Ca}, \mathrm{Mg}, \mathrm{pH}$ and O.M, followed by oil palm bunch ash + spent grain, and spent grain + poultry manure treatments respectively. When compared to NPK fertilizer treatment, oil palm bunch ash + poultry manure increased the soil $\mathrm{pH}, \mathrm{O} . \mathrm{M}, \mathrm{N}, \mathrm{P}, \mathrm{K}, \mathrm{Ca}$ and $\mathrm{Mg}$ by $26 \%, 94 \%, 17 \%, 6 \%, 10.2 \%$, $99.7 \%$ and $99.6 \%$ respectively.

The sole application of oil palm bunch ash increased the soil $\mathrm{pH}, \mathrm{O} . \mathrm{M}$ and $\mathrm{K}$ by $5.7 \%, \quad 16 \%$ and $13 \%$ respectively compared to the turkey manure. 
Emir. J. Food Agric. 2008. 20 (2): 01-09

http://www.cfa.uaeu.ac.ae/research/ejfa.htm

Table 5. The soil chemical composition after harvest of dikanut seedlings under different organic fertilizers.

\begin{tabular}{|c|c|c|c|c|c|c|c|}
\hline Treatments & pH & O.M & $\mathbf{N}$ & \multirow{2}{*}{$\begin{array}{c}\mathrm{P} \\
\mathrm{mg} / \mathrm{kg} \\
\text { soil }\end{array}$} & $\mathbf{K}$ & $\mathbf{C a}$ & Mg \\
\hline & $\mathrm{H}_{2} \mathrm{O}$ & & & & \multicolumn{3}{|c|}{$\mathrm{mmol} / \mathrm{kg}$} \\
\hline Control (no fertilizer) & $5.50 \mathrm{ab}$ & $0.25 \mathrm{a}$ & $0.02 \mathrm{a}$ & $3.52 \mathrm{a}$ & $0.02 \mathrm{a}$ & $0.030 \mathrm{a}$ & $0.036 \mathrm{~b}$ \\
\hline NPK 15-15-15 & $5.20 \mathrm{a}$ & $0.26 \mathrm{a}$ & $0.30 \mathrm{ef}$ & $32.25 \mathrm{fg}$ & $3.2 \mathrm{ef}$ & $0.01 \mathrm{a}$ & $0.008 \mathrm{a}$ \\
\hline Spent grain & $6.10 \mathrm{c}$ & $1.72 b$ & $0.14 b$ & $19.53 b$ & $2.36 \mathrm{~b}$ & $1.02 \mathrm{~b}$ & $0.75 \mathrm{c}$ \\
\hline Turkey manure & $6.50 \mathrm{~d}$ & $2.23 \mathrm{c}$ & $0.23 \mathrm{~cd}$ & $21.68 \mathrm{bc}$ & $2.67 \mathrm{~cd}$ & $1.98 \mathrm{~d}$ & $1.26 \mathrm{~d}$ \\
\hline Poultry manure & $6.40 \mathrm{~cd}$ & $2.31 \mathrm{c}$ & $0.26 \mathrm{de}$ & $24.29 \mathrm{~d}$ & $2.43 b$ & $1.92 \mathrm{~cd}$ & $1.30 \mathrm{de}$ \\
\hline Oil palm bunch ash & $6.90 \mathrm{e}$ & $2.64 d$ & $0.21 \mathrm{c}$ & $21.32 \mathrm{bc}$ & $3.08 \mathrm{de}$ & $1.67 \mathrm{c}$ & $1.21 \mathrm{~d}$ \\
\hline $\begin{array}{l}\text { Spent grain }+ \text { turkey } \\
\text { manure }\end{array}$ & $6.50 \mathrm{~d}$ & $3.23 \mathrm{f}$ & $0.27 \mathrm{de}$ & $27.82 \mathrm{e}$ & $2.75 \mathrm{~cd}$ & $3.18 \mathrm{~g}$ & $1.61 \mathrm{f}$ \\
\hline $\begin{array}{l}\text { Cocoa pod husk }+ \\
\text { spent grain }\end{array}$ & $6.58 \mathrm{~d}$ & $2.90 \mathrm{e}$ & $0.29 \mathrm{e}$ & $24.53 \mathrm{~d}$ & $2.44 b$ & $2.53 \mathrm{f}$ & $1.61 \mathrm{f}$ \\
\hline $\begin{array}{l}\text { Oil palm bunch ash }+ \\
\text { Spent grain }\end{array}$ & $7.00 \mathrm{e}$ & $3.29 \mathrm{f}$ & $0.29 \mathrm{e}$ & $32.40 \mathrm{fg}$ & $2.55 \mathrm{bc}$ & $2.60 \mathrm{f}$ & $1.68 \mathrm{fg}$ \\
\hline $\begin{array}{l}\text { Spent grain + poultry } \\
\text { manure }\end{array}$ & $6.80 \mathrm{de}$ & $2.91 \mathrm{e}$ & $0.32 \mathrm{fg}$ & $27.10 \mathrm{e}$ & $2.42 b$ & $3.55 \mathrm{~h}$ & $1.89 \mathrm{gh}$ \\
\hline $\begin{array}{l}\text { Cocoa husk }+ \text { turkey } \\
\text { manure }\end{array}$ & $6.60 \mathrm{~d}$ & $2.81 \mathrm{de}$ & $0.30 \mathrm{ef}$ & $30.43 \mathrm{f}$ & $2.88 \mathrm{~d}$ & $2.09 \mathrm{de}$ & $2.50 \mathrm{j}$ \\
\hline $\begin{array}{l}\text { Oil palm bunch ash }+ \\
\text { poultry manure }\end{array}$ & $7.00 \mathrm{e}$ & $3.32 \mathrm{f}$ & $0.36 \mathrm{~h}$ & $34.16 \mathrm{~g}$ & $3.60 \mathrm{~g}$ & $3.78 \mathrm{i}$ & $2.03 \mathrm{hi}$ \\
\hline
\end{tabular}

Treatment means within each column followed by the same letters are not significantly different from each other using Duncan Multiple Range Test at 5\% level.

\section{Discussion}

The least values of the growth parameters, the amounts of leaf $\mathrm{N}, \mathrm{P}, \mathrm{K}$, $\mathrm{Ca}$ and $\mathrm{Mg}$ of the dikanut seedlings under the control treatment were consistent with the initial low nutrient status of the soil used before planting the dikanut seeds. This could adversely affect the growth of the seedlings because the soil is poor in O.M, N, P, K, Ca and $\mathrm{Mg}$ contents.

However, the application of the organic residues to the soils with low fertility status enhanced favourable growth of dikanut seedlings. This result agreed with the work of Moyin-Jesu and Ojeniyi (2006) which reported rapid response of the growth of okra with the application of organic fertilizers.

The application of the residues, or soil amended with animal manure increased the soil O.M, N, P, K, Ca, Mg status and $\mathrm{pH}$. This was responsible for the significant

increase in the growth parameters (plant height, leaf area, leaf numbers, stem girth and root length).

The availability of soil nutrients was noticeably higher in amended oil palm bunch ash + poultry manure than those treated with spent grain + poultry manure and cocoa husk + turkey manure. This could be the reflection of higher nutrients content consisting of $\mathrm{K}, \mathrm{Ca}$ and $\mathrm{Mg}$ specifically in oil palm bunch ash and poultry manure respectively.

The observation was supported by Moyin-Jesu (2007) who reported that application of oil palm bunch ash + poultry manure increased effectively the growth, leaf and soil parameters of coffee. 
The increased effectiveness of the amended organic residues in improving the growth and leaf nutrients of dikanut seedlings compared to the sole application of the residues was due to the enhancement of their degradation by the poultry and turkey manures with lower $\mathrm{C} / \mathrm{N}$ ratio. Hence, improvement in expected to improve nutrient availability and soil fertility was expected to follow.

This finding was similar to that of Moyin-Jesu and Atoyosoye (2002) who reported that the nutrients' superiority of organically amended fertilizers compared to the ordinary forms of the materials.

The higher values of root length of dikanut seedlings under the organic fertilizer treatments was due to the fact that they significantly reduced soil bulk density, thereby enhancing better root elongation. This observation is supported by Folorunso (1999) who reported that spent grain amended with poultry manure reduced soil bulk density and enhanced root elongation for better nutrient uptake.

The continuous application of NPK fertilizer at $400 \mathrm{~kg} / \mathrm{ha}(2 \mathrm{~g}$ per $10 \mathrm{~kg}$ soil $)$ to the soil in which the dikanut seedlings are grown, would increase the rate of soil O.M decomposition leading to low value of soil O.M. Moyin-Jesu (2008) reported that continuous cropping and application of NPK fertilizer reduced the soil O.M content and release of nutrients.

The fact that NPK fertilizer improved the growth parameters of dikanut seedlings better than the control treatment is consistent with the high $\mathrm{N}, \mathrm{P}$ and $\mathrm{K}$ contents of the soil under the treatment.

The higher soil $\mathrm{pH}$ values under the oil palm bunch ash treatment confirmed its importance in increasing the availability of soil K, Ca, Mg and $\mathrm{Na}$ (Ojeniyi, 1995).

\section{Conclusion and Recommendation}

The use of sole and amended organic fertilizers increased the growth parameters, leaf and soil N, P, K, Ca, Mg, pH and $\mathrm{O}$. $\mathrm{M}$ of dikanut seedlings.
It is recommended that oil palm bunch ash amended with poultry manure applied at $8 \mathrm{t} / \mathrm{ha}(40 \mathrm{~g}$ per $10 \mathrm{~kg}$ soil) is very useful as fertilizer material for improving the nutrient content and ensuring sustainable cultivation of dikanut seedlings on a commercial basis.

The recommendation is in conjecture with the fact that inorganic fertilizers are very scarce, expensive and destroy soil properties when used regularly; as well as increase the need to revive the production of dikanut seedlings for income generation, industrial growth and an export-oriented economy.

\section{References}

AOAC (Association of Official Analytical Chemists). 1990. Official methods of Analysis $15^{\text {th }}$ ed. Arlington, Virginia, U.S.A.

Blakes, A. and Hartge G. 1986. Methods of soil analysis. Part ASA/SSSA. Madison, Wisconsin 363-375.

Folorunso, O. O. 1999. Use of plant residues for improving soil fertility and yield of okra (Abelmoschus esculentum L) and Amaranthus vividis L. Ph. D Thesis, Federal University of Technology, Akure.

Gee, G. W. and J. W. Bauder. 1986. Particle size analysis. In: Klute, A. (Ed.) Methods of Soil Analysis, Part 1. American Society of Agronomy. Madison, WI. 9:91-100.

Igwe, C. A., M. Zarei and K. Stahr. 2005. Mineral and elemental distribution in soils formed on the River Niger flood plain, Eastern Nigeria. Australian Journ. Soil Research 43:147-158.

Moyin-Jesu, E. I. and B. Atoyosoye. 2002. Utilization of Agricultural Wastes for the growth, leaf and soil chemical composition of cocoa seedlings in the 
nursery. Pertanika Jour. Trop. Agric. Sci. Malaysia 26(1):49-58.

Moyin-Jesu, E. I. 2003a. Incorporation of agro-industrial biomass and their effects on four successive crops of Amaranthus. Pertanika Jour. of Trop. Agric. Sci. 26(1):35-40.

Moyin-Jesu, E. I. 2004. Comparative evaluation of different plant residues on the soil and leaf chemical composition, growth and seed yield of castor bean (Ricinus communis). Pertanika Jour. of Trop. Agric. Sci. 27(1):21-30.

Moyin-Jesu, E. I. and S.O. Ojeniyi. 2006. Effects of sole and amended plant residues on soil nutrient contents and yield of okra (Abelmoschus esculentum L). Discovery and Innovation Jour. 18(4):318-326.

Moyin-Jesu, E. I. 2007. Effects of some organic fertilizers on soil and coffee (Coffee arabica L), leaf chemical composition and growth. University of Khartoum Jour. of Agric. Sci. 15(1):52-70.

Moyin-Jesu, E. I. 2008. Comparative evaluation of different organic fertilizers on the soil fertility, leaf mineral composition and growth performance of mango seedlings (Magnifera indica L). Emir. J. Food Agric. 20(1):18-30.

Obatolu, C. R. 1995. Nutrient balance sheet of Alfisol grown to coffee and maize using organic fertilizers. In: Proceedings of third annual Conference of All African Soil Science Society. "The International Conference on soil management and environmental protection". University of Ibadan, Ibadan, Nigeria. pp.250-256.

Odedina, S. O., M. Awodun and S. O. Ojeniyi 2007. Effect of cocoa husk on the soil fertility, leaf mineral composition and growth of tomatoes. Globa Jour. Environ. Studies 26(1):612.

Ogunwale, J. A and E. I. Udo. 1998. A laboratory manual for soil and plant analysis. Agronomy Department, University of Ibadan, Ibadan. 201-206.

Ojeniyi, S. O. 1995. "That our soil may not die" $10^{\text {th }}$ Inaugural lecture of Federal University of Technology, Akure. pp.3-5.

Steele, R. G. D., J. H. Torrie and D.A. Dickey. 1997. Statistical principle an approach. McGraw Hill companies Inc. 27-35. 